\title{
A simple rapid method for protein determination
}

\author{
JANUSZ CZAPSKI \\ Research Institute of Vegetable Crops, 96-100 Skierniewice \\ Konstytucji 3 Maja 1/3, Poland
}

(Received: November 26, 1989)

Abstract

\begin{abstract}
A simple, rapid method is described for determination of protein in the range of $20-200 \mu \mathrm{g}$. The procedure is based on the reaction between protein and amido black 10B. An insoluble residue is precipitated and the dye concentration in solution decreases. The difference between the optical density of the blank (without protein) and sample with protein is a linear function of protein content.
\end{abstract}

\section{INTRODUCTION}

Protein in dilute solution is commonly quantitated by the method of Lowry et al. (1951). This is a sensitive and simple method, but suffers from interference by many compounds. For example, phenols (Edreva and Cholakova, 1973), uric acids and xanthine (Bennet, 1967) can react with the Folin-phenol reagent to develop an intense colour. Various reducing agents like 2-mercaptoethanol, ascorbic acid, cysteine, dithiothreitol and bisulfite added to the buffer media during extraction of protein, interfere with the procedure (Bennet, 1967; Edreva and Cholak ova, 1973; Bram hall et al., 1969). Even solutions of $2 \%$ glucose and fructose (Edreva and Cholak ova, 1973) and Tris-(hydroksymethyl)-methylamine (Tris-Buffer) can also be a source of error (Kuno and Kihara, 1967). Direct determination of protein by the method of Lowry et al. (1951) is virtually impossible in many plant extracts, especially from fruits, where the protein content is extremely low $(\mathrm{Hulme}$, 1970) and phenolic compounds occur in large quantities ( $\mathrm{R}$ unk ova et al., 1972). Protein quantitation here requires previous troublesome purification. A simple and sensitive procedure for protein determination which does not suffer from interference by the many compounds mentioned above is described.

\section{MATERIALS AND METHODS}

The procedure is based on a reaction between proteins and a well known dye - amido balck 10B (naphtol blue black). During this reaction an insoluble residue is precipitated and the concentration of dye in solution decreases 
proportionally to the concentration of protein. Differences $(\Delta O D)$ between optical densities of the blank sample (without protein $-\mathrm{OD}_{\mathrm{b}}$ ) and the sample with protein $-\mathrm{OD}_{\mathrm{s}}$ are a linear function of protein content.

\section{REAGENTS}

(A) Amido black 10B (Amidoschwarz 10B, purchased from Merck) was prepared as $0.5 \% \mathrm{v} / \mathrm{v}$ solution in $7 \% \mathrm{v} / \mathrm{v}$ acetic acid.

(B) The dye solution used was prepared from (A) by dilution of $5.8 \mathrm{ml}$ of (A) with $7 \% \mathrm{v} / \mathrm{v}$ acetic acid to a volume of 11 .

The protein standards used were: calf thymus histone, albumin (human) fraction V (both purchased from P.O.Ch., Poland) and bovine serum albumin (purchased from Sigma). All protein standards were prepared in stock solutions of $1 \mathrm{mg} \cdot \mathrm{ml}^{-1}$ and $10 \mathrm{mg} \cdot \mathrm{ml}^{-1}$. Calf thymus histone was dissolved in 0.25 $\mathrm{M} \mathrm{HCl}$, albumin (human) fraction $\mathrm{V}$ in water, albumine from bovine serum respectively in water, $0.1 \mathrm{M}$ Tris- $\mathrm{HCl}$ buffer $\mathrm{pH}=8.5$ and $1 / 15 \mathrm{M}$ phosphate buffer $\mathrm{pH}=6.8$.

\section{PROCEDURE}

Samples containing $20-200 \mu \mathrm{g}$ of protein were pipetted into $10 \mathrm{ml}$ glass centrifuge tubes and the volume adjusted to $1 \mathrm{ml}$ with the appropriate buffer solution or water. Blank samples contained $1 \mathrm{ml}$ of the appropriate solution without protein. To each tube (including blank) $4 \mathrm{ml}$ of amido black 10B solution (B) were added and the tubes were shaken for $30 \mathrm{~s}$. Next they were cooled for $30 \mathrm{~min}$ at $2^{\circ} \mathrm{C}$ and centrifuged at $2^{\circ} \mathrm{C}$ at $5500 \mathrm{rpm}$ for $15 \mathrm{~min}$. After centrifugation supernatants were decanted and the optical density measured in a "Specol" Zeiss photometer at $640 \mathrm{~nm}$ against 7\% v/v acetic acid using absorption cells with a $0.496 \mathrm{~cm}$ light path. The optical density of the blank sample (without protein) equalled 0.670-0.690. Differences $(\Delta O D)$ between optical density of the blank sample $\left(\mathrm{OD}_{\mathrm{b}}\right)$ and samples with a known amount of protein $\left(\mathrm{OD}_{\mathrm{s}}\right)$ were plotted against those of protein content. Each determination was repeated 3-4 times. To avoid errors, unknown amounts of protein in samples should be analysed in at least three different concentrations; in practice, three different volumes of the same sample should be taken for analysis to be sure that the proper amount of protein is taken for determination. A well visible residue on the bottom of the centrifuge tube after centrifugation and decantation indicates that the unknown amount of protein falls in the range of 20-200 $\mu \mathrm{g}$. The described method was compared with the methods of Lowry et al. (1951) and Kuno and Kihara (1967) using pea epicotyls (Pisum sativum) and mushrooms (Agaricus bisporus (Lange) Sing.). Four-day-old epicotyls and fruit body of mushrooms were ground with cold $1 / 15 \mathrm{M}$ phosphate buffer $\mathrm{pH}=6.8$ and, after centrifugation, the supernatants were adjusted to $5 \mathrm{ml}$ with the grinding buffer. These crude protein-containing 
extracts were light yellow (pea epicotyls) and dark yellow (mushrooms), indicating the presence of oxidizing phenols. The proteins from the crude extracts were purified by precipitation with cold acetone after which the residue was re-dissolved in the grinding buffer. The protein concentration in the crude and purified extracts were determined by the amido black 10B, Low ry et al. (1951) and K uno and Kihara (1967) methods. A crude extract (supernatant) from the green receptacle of strawberry fruit was used as a source of natural phenols. The receptacle was homogenized with a $1 / 15 \mathrm{M}$ phosphate buffer $\mathrm{pH}=6.8$ followed by centrifugation. An appropriate volume of $50 \%$ trichloracetic acid (TCA) was added to part of this extract to bring the concentration to $7 \%$ and, after centrifugation the crude and $7 \%$ TCA strawberry extracts were added to purified tested pea protein after which the protein was determined using the three above mentioned methods.

\section{RESULTS}

Figures 1 and 2 illustrate linear calibration curves for the tested proteins. For calf thymus histone (Fig. 1), two linear curves were obtained:

I - for 20-120 $\mu \mathrm{g}$ protein,

II - for $120-200 \mu \mathrm{g}$ protein.

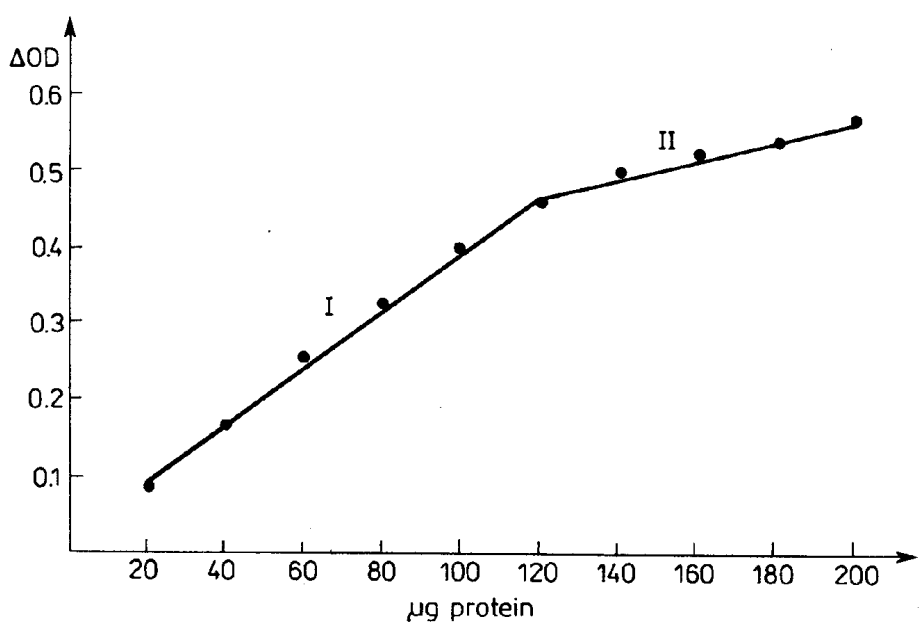

Fig. 1. The relationship between amount of protein and difference between the optical density $(\triangle O D)$ of the blank $\left(O D_{b}\right)$ and sample $\left(O D_{s}\right.$ ) for calf thymus histone in $0.25 \mathrm{M} \mathrm{HCl}$ (mean of four replicates). I $-20-120 \mu \mathrm{g}$ protein, II $-120-200 \mu \mathrm{g}$ protein

The curves differ significantly with regression values listed in Table 1 . For the concentration range of $200-220 \mu \mathrm{g}$ histone in $0.25 \mathrm{M} \mathrm{HCl}$, the concentration of amido black 10B was to low for full precipitation of protein. The calibration curve then reached a "plateau". Further increase of protein above $220 \mu \mathrm{g}$ led to 
Table 1

Parameters for calibration curves

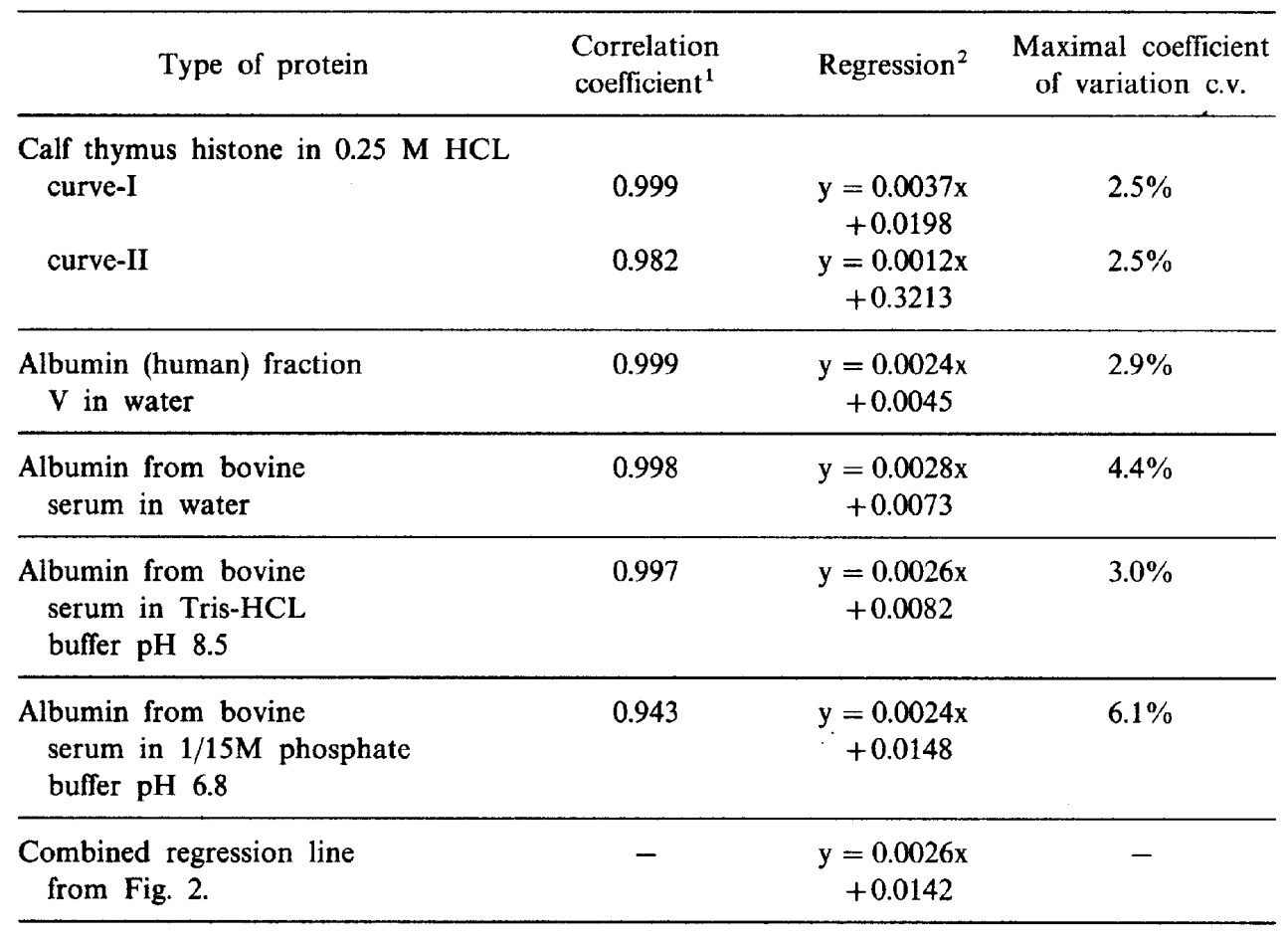

${ }^{1}$ Significant at $\mathrm{p}=0.99 .{ }^{2} \mathrm{x}-$ protein content $(\mu \mathrm{g}), \mathrm{y}-\Delta \mathrm{OD}$.

perturbation of the equilibrium of the reaction between protein and amido black, causing solubilization of the residue and a nonlinear decrease of the optical density. These phenomena were observed for all of the tested proteins. The calibration curves differed slightly from that of calf thymus protein reaching a "plateau" at 220-240 $\mu \mathrm{g}$. Solubilization of protein occurred above $240 \mu \mathrm{g}$ protein. The relationships between $\triangle \mathrm{OD}$ and protein content for albumin (human) fraction $\mathrm{V}$ in water, albumin from bovine serum in water, $0.1 \mathrm{M}$ Tris- $\mathrm{HCl}$ buffer $\mathrm{pH}=8.5$ and in $1 / 15 \mathrm{M}$ phosphate buffer $\mathrm{pH}=6.8$ are presented on Figure 2. In contrast to calf thymus histone, only single linear calibration curves were obtained. The relationship between $\triangle O D$ was highly correlated with the amount of protein in all tested samples. The correlation coefficients of equations of regression and maximal coefficients of variation are presented in Table 1. Since the regression parameters of calibration curves (Fig. 2) did not differ significantly at $p=0.99$, a combined regression line with confidence limit at $p=0.95$ was computed (Table 1) and plotted (Fig. 3). The results of determination of unknown amounts of protein in plant samples using amido black 10B, Lowry et al. and Kuno and Kihara methods are 


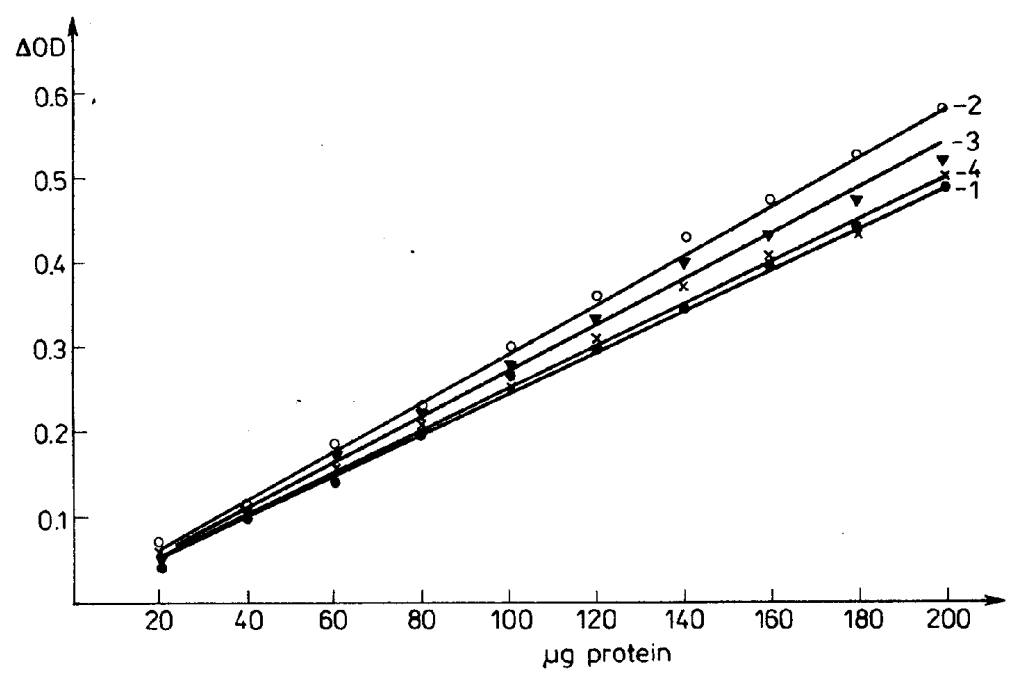

Fig. 2. The relationship between amount of protein and difference between the optical density $(\triangle O D)$ of the blank $\left(O D_{b}\right)$ and sample $\left(O D_{s}\right)$ for: 1 - albumin (human) fraction $V$ in water (mean of three replicates); 2 - bovine serum albumin in water (mean of three replicates); 3 - bovine serum albumin in $0.1 \mathrm{M}$ Tris- $\mathrm{HCl}$ buffer $\mathrm{pH} 8.5$ (mean of four replicates); 4 - bovine serum albumin in $1 / 15 \mathrm{M}$ phosphate buffer $\mathrm{pH} 6.8$ (mean of three replicates)

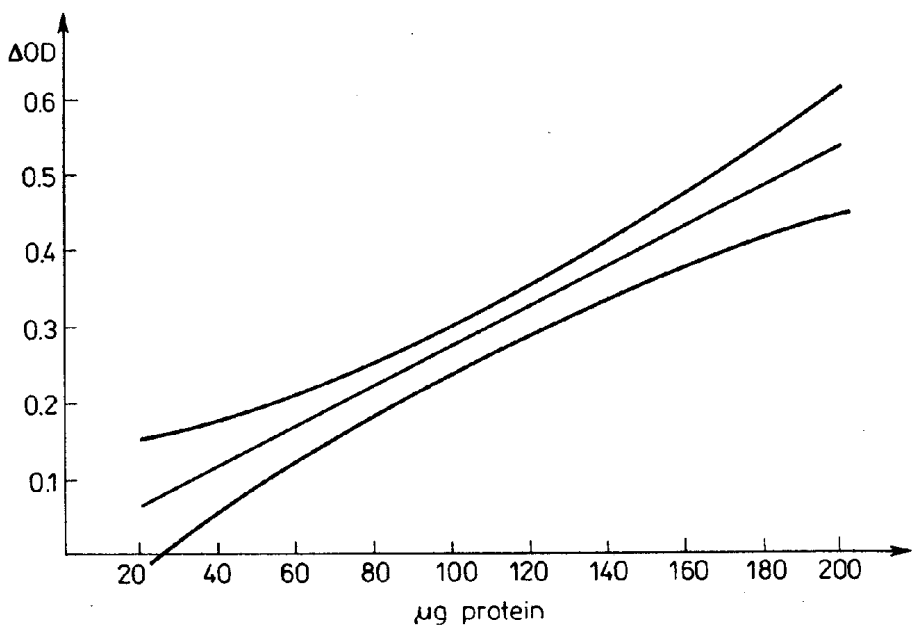

Fig. 3. The difference between the optical density $(\triangle O D)$ of the blank $\left(O D_{b}\right)$ and sample $\left(O D_{s}\right)$ as a linear function of protein content. The central regression line and confidence limit at $p=0.95$ have been computed from the calibration curves presented on Figure 2.

summarized in Table 2. There are no statistically significant differences at $p=0.95$ among these three methods for purified protein and between the amido black $10 \mathrm{~B}$ and $\mathrm{Kuno}$ and $\mathrm{Kih}$ ara methods for all treatments (Tables 2 and 3). The values presented in Table 3 of coefficients $a$ and $b$ of the regression equation $\mathrm{y}=b \mathrm{x}+a$ for purified protein analysed by all three tested 
Table 2

Comparison of protein determination by the amido black 10B, Low ry et al. (1951) and K u n o and Kihara (1967) methods

\begin{tabular}{|c|c|c|c|}
\hline \multirow[b]{2}{*}{ Analysed sample } & \multicolumn{3}{|c|}{ Concentration of protein $\left(\mathrm{mg} \cdot \mathrm{ml}^{-1}\right)^{*}$} \\
\hline & $\begin{array}{l}\text { Method 1 } \\
\text { (amido black } \\
\text { 10B) }\end{array}$ & $\begin{array}{l}\text { Method } 2 \\
\text { (Lowry } \\
\text { et al.) }\end{array}$ & $\begin{array}{c}\text { Method } 3 \\
\text { (Kuno and } \\
\text { Kihara) }\end{array}$ \\
\hline \multicolumn{4}{|l|}{ Pea epicotyls } \\
\hline \multicolumn{4}{|l|}{ Purified protein from } \\
\hline crude extract & $0.184 \mathrm{a}$ & $0.200 \mathrm{a}$ & $0.180 \mathrm{a}$ \\
\hline Crude extract & $0.207 \mathrm{a}$ & $0.383 \mathrm{~b}$ & $0.200 \mathrm{a}$ \\
\hline \multicolumn{4}{|l|}{$\begin{array}{l}\text { Purified protein }+0.1 \mathrm{ml} \\
\text { crude extract from }\end{array}$} \\
\hline \multicolumn{4}{|c|}{$\begin{array}{l}\text { Purified protein }+0.1 \mathrm{ml} \\
\text { crude extract from strawberry } \\
\text { receptacle after addition }\end{array}$} \\
\hline trichloracetic acid (TCA) & $0.154 \mathrm{a}$ & $1.28 \mathrm{~d}$ & $0.158 \mathrm{a}$ \\
\hline \multicolumn{4}{|l|}{ Mushrooms } \\
\hline Purified protein & $0.392 \mathrm{e}$ & $0.394 \mathrm{e}$ & $0.391 \mathrm{e}$ \\
\hline Crude extract & $0.416 \mathrm{e}$ & $3.54 \mathrm{f}$ & $0.411 \mathrm{e}$ \\
\hline \multicolumn{4}{|l|}{ Coefficient of variation c.v. $\%$} \\
\hline Pea epicotyls & 12 & 76.7 & 9.2 \\
\hline Mushrooms & 3.4 & 85.7 & 3.3 \\
\hline
\end{tabular}

* Mean values followed by the same letter do not differ significantly at $p=0.95$ using Duncan test.

Table 3

Statistical evaluation of the methods

\begin{tabular}{|c|c|c|c|c|c|}
\hline $\mathrm{x}$ & $\mathbf{y}$ & Treatment & $\begin{array}{c}\text { Equation } \\
\text { of regression }\end{array}$ & $\begin{array}{c}\text { Correlation } \\
\text { coefficient } \\
r^{1}\end{array}$ & $\begin{array}{l}\text { F-value at } p=0.95 \\
\text { for regression } \\
\text { coefficient assuming: } \\
\qquad \begin{array}{c}b=1 \\
a=0\end{array}\end{array}$ \\
\hline Method 1 & & $\begin{array}{l}\text { purified } \\
\text { protein }\end{array}$ & $y=0.929 x+0.029$ & 0.998 & $2.81 \mathrm{NS}^{2}$ \\
\hline Method 2 & & $\begin{array}{l}\text { purified } \\
\text { protein }\end{array}$ & $y=1.085 x-0.036$ & 0.995 & $3.79 \mathrm{NS}$ \\
\hline Method 1 & Method 3 & $\begin{array}{l}\text { all treat- } \\
\text { ments }\end{array}$ & $y=0.984 x+0.003$ & 0.998 & $1.03 \mathrm{NS}$ \\
\hline
\end{tabular}

Method 1 - amido black 10B;

Method 2- Lowry et al.;

Method 3- Kuno and Kihara.

${ }^{1}$ Significant at $p=0.99 .^{2} F_{\text {caleulated }}<F_{\text {theoretical. }}$ 
methods and for protein from all treatments analysed by the amido black 10B and Kuno and Kihara methods did not differ significantly at $p=0.95$ from these assumed, $b=1, a=0$, because the calculated F-values were lower from the theoretical $F$ of Snedecor. So all of the tested methods for purified protein and two of them (amido black $10 \mathrm{~B}$ and $\mathrm{K}$ un o and $\mathrm{K}$ ih a ra) for all treatments can be recognized as equivalent. Some slight differences between the results for purified protein and crude extract of pea epicotyls analysed by the amido black $10 \mathrm{~B}$ and Kuno and Kihara methods were probably caused by incomplete precipitation of protein by acetone. This probably had an effect on the values of variation coefficients (Table 2). The presence of oxidizing phenols (yellow colour of crude extracts) influenced the estimation of protein by the method of Low ry et al. (Table 2). Addition of extracts from green strawberry receptacles to the tested samples of purified pea epicotyl protein, considerably influenced the results of determination by the method of Low ry et al. (effect of phenols). The results were 6-7 fold higher than those analysed by other tested methods. Only a slight decrease in the results of protein determination by the amido black $10 \mathrm{~B}$ and $\mathrm{Kuno}$ and $\mathrm{Kih}$ a r a methods could be observed as a result of the phenols effect (Table 2).

\section{DISCUSSION}

Comparison of the method presented above with the other methods utilizing amido black for estimation of protein ( $\mathrm{K} \mathrm{uno}$ and Kihara, 1967; Bramhall et al., 1969) indicates that this method is simple and economical. Kuno and Kihara (1967) used a membrane filter to absorb protein, then the filter was stained with amido black and after washing, the residue was released and the colour determined. Using this procedure they could determine only 10-50 $\mu$ g of protein. Bramhall et al. (1969) spotted protein on filter paper and after drying, washing and fixation the further procedure for staining and releasing of the dye was similar to that of the Kuno and Kihara (1967) method. Using amido black (naphtalene blue black) they could determine 50-200 $\mu \mathrm{g}$ of protein. The amido black 10B method described above makes it possible to measure protein in the range of $20-200 \mu \mathrm{g}$. It requires fewer analytical operations, so it is less time consuming and more economical than the procedures of Kuno and Kihara (1967) and Bramhall et al. (1969). Besides this, it shows high specificity for protein. Other substances such as phenols or reducing agents which interfered in the method of Lowry et al. (1951) practically do not disturb this procedure. It should be stressed when using this method the visible residue on the bottom of centrifuge tube after centrifugation and decantation should be closely observed. When the amount of protein is in the range of the "plateau" or solubilization, a nonlinear decrease of the optical density is observed. Sometimes for a highly coloured sample (brown, redish brown), colour interferes with the dye solution, causing an 
increase of the optical density. There are two other methods described in literature for protein determination which involve the binding of Coomassie Brilliant Blue G-250 to protein (Bradford, 1976; Sedmac and Gross berg, 1977). They differ only with respect to the solution in which the dye is dissolved. The binding of the dye to protein causes a shift in the absorption maximum of the dye from 465 to $595 \mathrm{~nm}$ and it is the increase in absorption at $595 \mathrm{~nm}$ which is monitored. The range of protein determination is $10-100 \mu \mathrm{g}$ (Bradford, 1976) and 0.5-50 $\mu \mathrm{g}$ (Sed mac and Grossberg, 1977) and limit of detection 5 and $1 \mu \mathrm{g}$, respectively. These methods are sensitive and simple but they suffer from interference by SDS (sodium dodecyl sulfate), urea, phenol, EDTA, Tween, sodium sulfate and Triton X-100 at relatively high concentrations. Some nonlinearity in the response pattern can be observed but rectilinear curves from $0.5-50 \mu \mathrm{g}$ protein can be obtained by plotting the ratio of absorbance $620 / 465 \mathrm{~nm}$ (Sedmac and Grossberg, 1977). The methods above mentioned are presented as general procedures for protein analysis and may have been shown to be appropriate if plant protein had also been analysed for comparison.

\section{REFERENCES}

Bennet T. P., 1967. Membrane filtration for determining protein in the presence of interfering substances. Nature, 213: $1131:-1132$.

Bradford M. M., 1976. A rapid and sensitive method for the quantitation of microgram quantities of protein utilizing the principle of protein dye binding. Anal. Biochem. 72: 248-254.

Bramhall A., Noack N., Wu M., Loewenberg J. R., 1969. A simple colorimetric method for determination of protein. Anal. Biochem. 31: 146-148.

Edreva A., Cholakova N., 1973. Nekotorye oshibki pri opredeleni belkovykh veshchestv metodom Louri. Fiz. Rast. 22: 204-207.

Hulme A. C., ed., 1970. The biochemistry of fruits and their products. Academic Press, London and New York.

K uno H., Kihara H. K., 1967. Simple microassay of protein with membrane filter. Nature, 215 : 974-975.

Lowry O. H., Rosebrough N. J., Farr A. L., Randall R. J., 1951. Protein measurement with the Folin phenol reagent. J. Biol. Chem. 193: 265-275.

Runkova L. V., Lis E. K., Tomaszewski M., Antoszewski R., 1972. Function of phenolic substances in the degradation system of indole-3-acetic acid in strawberries. Biologia Plantarum, (Praha), 14: 71-81.

Sedmac J. J., Grossberg S. E., 1977. A rapid sensitive and versatile assay for protein using Coomassie Brilliant Blue G-250. Anal. Biochem. 79: 544-552.

\section{Prosta i szybka metoda oznaczenia białka}

\section{Streszczenie}

Przedstawiono prostą i szybką metodę oznaczenia bialek w zakresie 20-200 $\mu \mathrm{g}$. Procedura oznaczenia polega na reakcji między białkami a czernią amidową 10B.

W wyniku tej reakcji strąca się nierozpuszczalny osad, a stężenie barwnika w roztworze maleje. Różnica $(\triangle \mathrm{OD})$ między gęstością optyczną ślepej próby (bez białka) i próby z białkiem jest liniową funkcją zawartości bialka. 